\title{
Studying and identifying natural dangers of Shanderman masal basin
}

\author{
Abbasali Sani Chaleh Saraei ${ }^{1}$, Fereydoon Azad Gholami Khasmakhi ${ }^{2}$, Alireza Abbasi Najafabadi ${ }^{3}$ \\ Received:20.08.2015 \\ Revised:25.09.2015 \\ Accepted: 30.10.2015
}

\begin{abstract}
Comprehensive consideration of basin in the view of natural condition is one fundamental solution of ecosystem management that leads to better preservation of natural resources. Changes of land use and climate fluctuations are factors that affect natural cycle of water in ecosystem. Slope of domain, their classification, slope of bed, vegetation, type and shape of land and kind of product cultivated in land, flowing regimes or the way of flow of cortical regime, deep regime, permanent and quarterly regime, lithology and thickness of constructors and type of constructor and runoff existed in a basin accompanied by shape of basin are cases that affect natural dangers of basin. This research regarding method is descriptive-analytic and by benefiting field observation and attributional and library studies considers natural dangers of shanderman basin and the aim of above research is considering natural dangers in Shanderman basin. Considerations shows that in Shanderman basin there are various natural dangers that were related to topography condition, geology, soil, geomorphology, vegetation, hydrology and climate of the region and totally the most danger exist in flood basin and thereafter erosion. In fact most floods has been done due to much rain and caused destruction of communicative roads, destruction of bridge and financial damages to agricultural lands and so on. In recent years by change of land use at basin and destruction of vegetation these dangers has accelerated. It is hoped authorities can have necessary plan for confrontation with existing dangers in Shanderman basin regarding findings of research.

Keywords: consideration, natural dangers, basin, shanderman.
\end{abstract}

\section{Introduction}

Iran is an extensive country that due to specific situation and topographic situation has different weather. Degree of average annual rain was mentioned $224-275 \mathrm{~mm}$ that about one third average rain of lands $(800 \mathrm{~mm} 0$ and is less than one third of average rain of the earth $(1133 \mathrm{~mm})$. Therefore most part of Iran is located in dry weather of the world. In addition to low rain, severe fluctuation of rain in daily scale, season and annual are features that cause insufficient certainty toward getting required minimum rain for consumption of agriculture, food of superficial flow and underground water reservoir and human consumption. Regarding existence of severe negative fluctuation in rains of different region in the world, occurrence of this drought imposes destructive damage on agriculture and economy sections. In relationship with flood and natural dangers different researches have been done in the world. In 1936 America congress approved law of controlling flood and engineering organizations made army as the organization of federal government, responsible for management of great basin of country. Burton and Kate 1964) defines

Author's Address

1. Department of Geography Scientific Faculty, Rasht Branch, Islamic Azad University, Rasht, Iran

2,3. Department of Geography Scientific Faculty, Najafabad Branch, Islamic Azad University, Najafabad, Iran these dangers: physical factors of environment that are dangerous for human and are created through external forces are better than human power. Natural or physical dangers have been defined as divine rules (Moghimi and Goodarzinezhad, 2003, $\mathrm{p}$ 10). Wite(1945) in a comprehensive plan for management of flood Palins has used unconstructive methods with defensive and constructing works. Maskedi(1989) dangerous capabilities due to being colonial and change of population residing in mountainous places(also mountain situated in urban centers) is increasing.

Rosel in (1987) by studying Britain flood in 1970 and also by observation that has from North America emphasized type of behavior that was done in mouth of the flood plain such as encroachment to flood atmosphere, significant perception of danger and inattention to administrative viewpoints and knew them the factor of increasing disaster and destruction of flood. Ramezani and Abdollahi(2003) in considering rain-runoff of basin of Masouleh city in Guilan say by increase of rain in the basin and on the other hand destruction of vegetation of the basin including forest and pastures... flood threats the region. Ramezani(2003) in a paper entitled as considering and identification of the factor of Mordad flood in 1999 in Masoule in Guilan says: researchers who have considered flood of ninth of 
Mordad in 1999 have identified the factor of rain as the factor of creating flood. In case the factor of rain is not the reason of flood but flood was a geomorphological phenomenon that storage of water from past has flew explosively toward sand runoff toward lower side. Alizadeh(2004) in a research of Islamic azad university of Rasht entitled as the greatest flood in hydrology(case study of Gorganroud of Talesh basin) did a research. Rezaei Hajidehi, Parviz(2009) in a paper entitled as synoptic analysis of flood event in Masouleh basin stated the origin of models of planetary, is Mediterranian and black sea and models of anticyclone is mostly on Caspian sea and black sea that mentioned systems have created flood based on features or their stop on basin of Masoleh from 1-3 fallowing days. 34 out of selective flood are one-day, 13 cases are 2-days and 14 cases are 3-days. Regarding time distribution the most floods has been recorded in September to October and at the end of winter to the beginig of spring. Guilan province regarding climate and specific geographical situation is manifested as a province without problem. Whereas it has different problems in every place. For example with a severe rain flood flows and by period of long rain problem $\mathrm{f}$ erosion and sedimentation is created although significant rains exist Guilan experiences drought and on the one hand it overshadows snow. This province has 74 big and main rivers and considering natural and human problems in river basin of the province has specific importance. Shanderman basin in Masal like basins of Guilan has got natural events and isn't out of this rule. Therefore this paper seems to identify above natural dangers and regarding its problems do necessary planning for it.

\section{Material and methods}

Shanderman basin is located in geographical coordinates of 481623 to 490640 degree of eastern length and 371740 to 372540 degree of northern width this basin in Masal city is one basin that rooted from haights of $2800 \mathrm{~m}$ of Sadereh sar in West, Koohdiga in northwest and Kooh Dilmeh and Barzdar in southwest and and with various braches after passing a road it passes through different regions like Salarom Lachor, Bringah, Afjafa, this river that has branches like Goorkesh, Dasht Zamin, Varam, is from northwest and
Khoshkeh Darya and Mayzo are from southwest join together at the region of Lachoor and Leili Kan and conform great river of Shanderman.This basin locates at the north of Masal city politically and its process was from west to east and finally after passing long way arrives to Caspian Sea. The most important existing data in this research were statistics and statistical data of weather station and hydrometrics that has been received from meteorology organization and regional water organization of guilan province. This statistic was used from different stations and after statistical estimation and convergence of data was used. In geological consideration of basin geology maps of scale 1:250000 of Guilan province and geology maps of scale 1:100000 shits of Bandar e Anzali and in topography consideration and network of basin water geographical organization maps of army to sheets of Masal and Taharom and in consideration of soil of basin capability and talent map of lands scale 1:250000 of guilan province and in consideration of vegetation of basin applied map and lands of scale 1:100000 of Anzali sheet have been used. Method of consideration in this research was library and attributional and field studies and in library method firstly information related to natural dangers and attributional studies and then providing meteorology statistics and hydrometrics in discussion of climate and hydrology was considered and finally for identifying basin and existing dangers in it field research were done and supplying photo and interviewing different people were done.

\section{Natural dangers of basin}

Among different natural factors that make an environment inconsistent or cause consistency or special balance we can point geological ,climate, topographical, geomorphological and vegetation factors and among human factors type of life and civil activities can be pointed out. Although factor of spending time is counted adetermining factor and may most factors change over time some factors may be constant over time (lithology, topographic condition and so on) and some other factors especially human factors were generally changing (tectonic movements like earthquake and civil activities and social-economic changes) so by considering above factors and number of inconsistent events and field of developing them 
along time we may predict their occurrence in future.

\section{-Geology}

In producing runoff and amount of its severity against erosion, different constructors of geology can have significant effect. Generally usual appearance of basin, the way of erosion, density and pattern of drainage and producing superficial runoff, all are affected by geology of the basin. In shanderman basin existence of constructors like limestone, candied, and thin layer limestone, dolomitic limestone, sand stone, tuff and yellow tuff sand stones that have much sensitivity against factors of erosion with any use change that causes destruction of vegetation. Factors affecting flood and other natural events are slip and falling.

\section{- Fault}

In shanderman basin there are main and subordinate small and big faults that can create events in rural regions of studying area. Small faults exist at southeast of shanderman that was
$3.5 \mathrm{~km}$ long and started from Kooh Absho and Sekhal at the southeast and by horizontal process continues from regions like Zarbil, korobar, Kach, Alaleh posht and Savadbar, Falakehvir, Gagoor posht and forest of Gagoor posht and along with south of basin. Another fault that joins from south of basin to this small fault and has process of northeast and its minimum length is $2.5 \mathrm{~km}$. it starts from Gavkoor posht and goes along with Kooh sar, jirshir, larzaneh forest, Aref Jafa, Salaro, Varsho, Soo posht, Zarfash khooni and Bring and toward northwest of basin. Another small fault that was from koosar and joined previous fault was at northeast process and passes through regions like Lachoor, Amradol, and lasht and Leilikan. At the center of basin there is another small fault that was observed at low distance with itself and in the form of semi-circle and polygon and covers regions like Kolgol, Hajibijar, Jaskens and Koliteh posht and Bazkamchay.

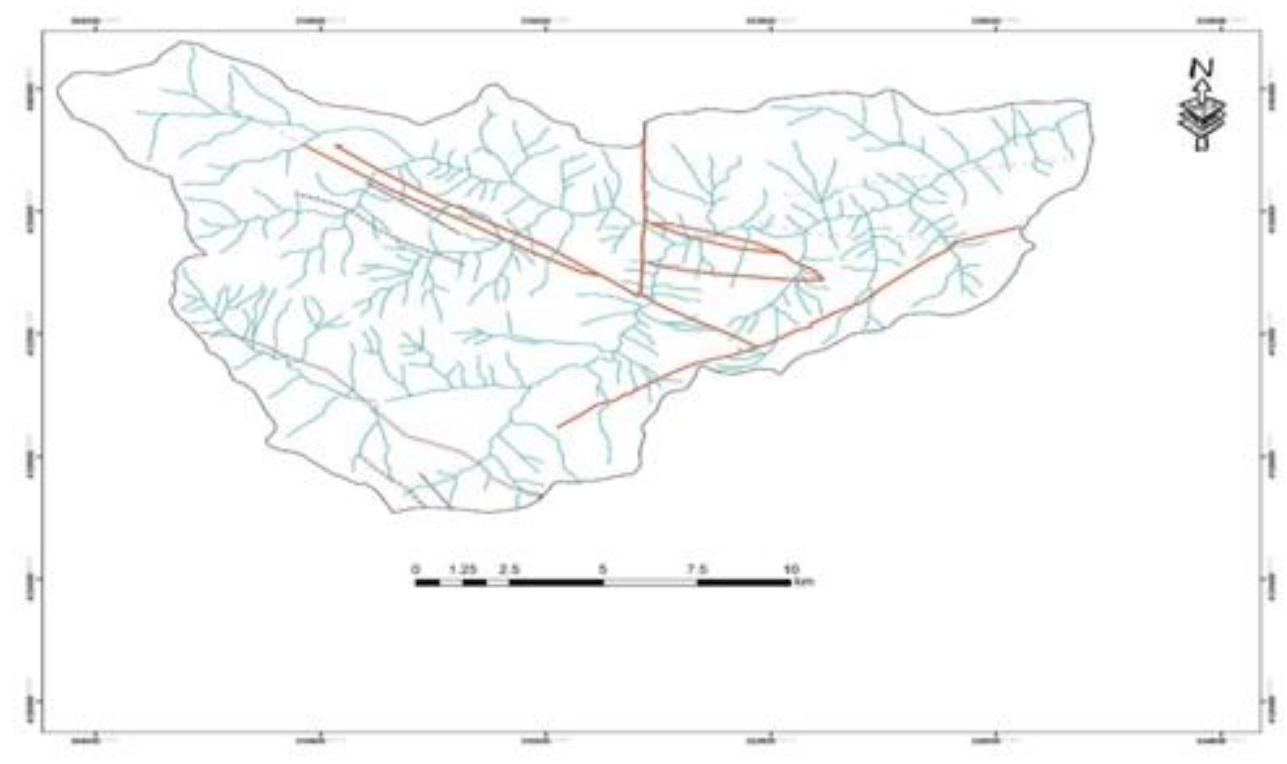

Figure 1: Map of fault of shanderman basin

\section{- Slope:}

Topographical condition of studying region shows that about $80 \%$ of area of basin has slope more than $20 \%$ and in fact it shows that the highest level of basin had high slope and so this factor can play important role at creating flood and other events regions such as: Haji bijar, Sefid soteh, Brim Belanga, sorkheh Sangan, zarafsh Khooni and so on in shanderman basin are at more than $20 \%$ slopes.

\section{- Vegetation}

Generally vegetation of basin of shanderman is consisting of two sections of forest and pastureland each having ecological feature and type of coverage related to itself. In this basin parts in height and in output of basin that mostly cover gardens and agriculture lands are observed in the 
form of destructed and dispersed forest and gradually in higher height massive forest are seen and in heights pastureland are observed. One factor that makes the role of vegetation more significant is change of land use that usually happed in rural area that causes to destroy ecosystem of the region and forest and gradually regarding slope and height of these regions erosion becomes more severe and sewage increses destruction factor with much speed and power so the role of vegetation in preventing some natural events is elective.

\section{- Topography}

Shanderman basin is mountainous regarding topography and has the most area of slope above $20 \%$ although having vegetation it can be effective factor at natural events by a glance to topographical map of the basin we observe that most rural regions have been created at the side of river and valleys that regarding mountainous area and much slope the severity of runoff becomes more and can be serious danger for rural regions.

\section{- Networks of water}

Shanderman basin is consist of two main head branches of Shanderman and Goorkesh that they are different regarding length of waterways and its branches and higher branch and lower branch each has a big sub basin and various big and small parcels with local names such as plain of Zamin
Varam, Mayzo, Khoshkeh and so on. These two sub basins after passing a mountainous direction and drainage of subordinate networks join in lower level basins and in villages of lachor. Mountainous and high slope of shanderman basin and inattention to the principle of territory of river and destruction of vegetation in river side and lack of implementing operation of watershed and time of concentration of basin was 2.31 and rain in basin and flood in this region are cases that residents of region should be aware of occurrence of natural dangers such as flood after severe rain because this basin is a permanent basin and has rectangular and hand fan forms.

\section{- Physiography}

a case that is effective at greatness of degree of flood in basin is area of basin that regarding studying basin is high in the view of area we can have specific attention and also factor of area in continuity of river flow in great basin was more than small basins that shanderman basin is not out of this case other factors are shape of basin that considering basin was rectangular regarding form and longtime of concentration of basin is another topography of basin that shows time runoff comes downside from upside that regarding obtained time of concentration runoff arrives exit part of basin during an hour and it shows flood of basin.

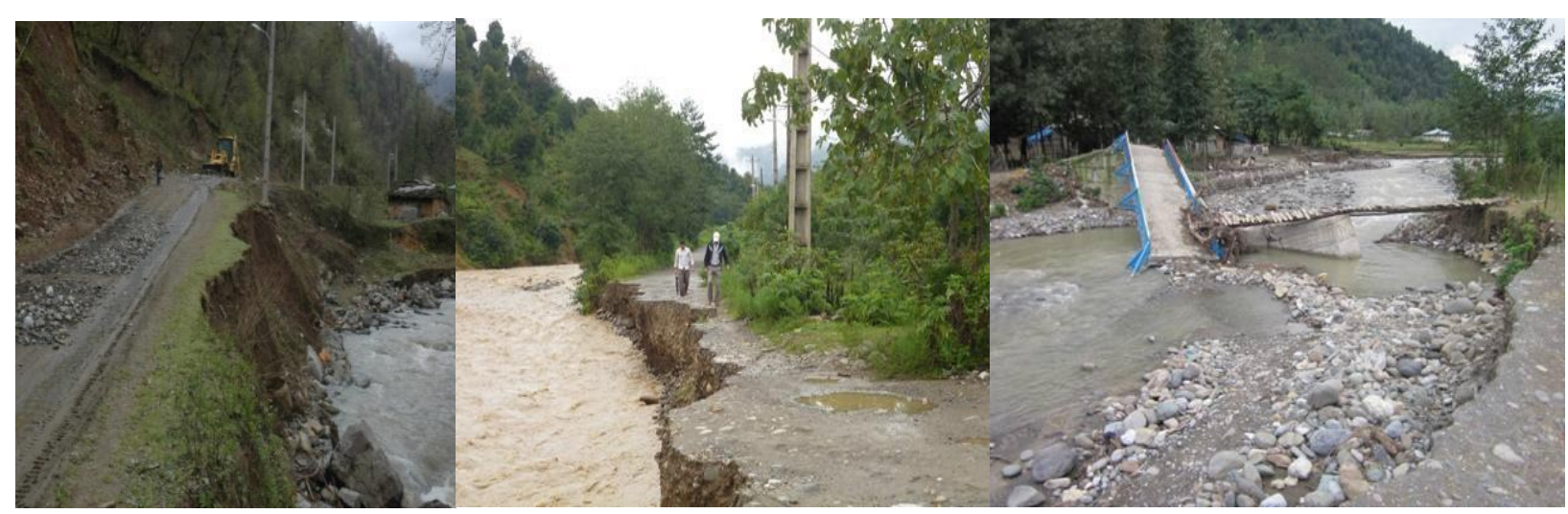

Figure 2: Physiography of Shanderman

\section{- Erosion}

Soil erosion is identified as a global problem in current century as according estimation of FAO annually 3 billion hectare of agriculture lands are exited from access due to erosion Iran isn't excepted from this rule as based on statistics of hydrometrics stations annual $2.5-4$ billion tonz of soil of 100 million hectares of watersheds of country is getting erosion. Different forms of erosion in shandrman basin are explained as:

\section{Superficial erosion}

This type of erosion is seen in surface (in upper part of pasture of basin). The most important factor creating this type of erosion isgeological, 
climatological, topographical and human factors. Among mentioned factors human factors are more important than other ones. Human factors like lack of observing correct principles of pasture keeping and cutting forest trees causes strengthening this type of erosion. Excessive grazing, existence of additional animals'causes' distance of pasture from climax state.

\section{Rill erosion}

This type of erosion is mostly seen in high regions of basin (pasture). Erosion in the view of dimension and density is less than surface erosion and limited area of basin is encompassed. Rill erosion due to low resistance of soil against dispersion of its particles and also force of cutting is resulted from melting snow in steep slope. This type of erosion is observed in Sorkheh sangan region.

\section{Gully erosion}

This type of erosion is not significant in basin. Due to vegetation of forest degree and extensiveness of this form of erosion toward rill and surface erosion is less. The most important reason of creating gully erosion in the region is freezing and melting snow periodically, existence of sensitive constructor and excessive graze in these lands.

\section{Stream erosion}

The meaning of stream erosion is destructing bottom and sides of waterways. This type of erosion is not prevalent in the region and it is seen in northern parts(uppersie pasturesland) due to pasture coverage and steep slope of waterways and in other sections due to condensed forest coverage and high thickness coefficient of waterways amount of this type of erosion is not seen in this region or its amount is low. This type of erosion occurs due to snow melt cause increase of water pollution. Of course severe and short-time rains are effective in preceding this type of erosion.

\section{Mass erosion}

This type of erosion is created due to high humidity, relative lo resistance of stones an slope.it is observed in forest and pasture area dispersely this type of erosion occurs when force of weight of material is more than resistance force resulted from soil cutting. Different factors like rain, snow avalanche affect creating mass erosion.

\section{Flood erosion}

In this type of erosion usual rain fill concavity, storages, lake water and pools and saturates soil and if more severe rain falls almost all $\mathrm{f} t$ flows and finally moves from valleys and mountains toward lower sides. In regions of shanderman river especially in daran region it causes destruction of subordinate communicative road (Mehdi Kasi reporter of Masal news from Chalehsara village, date of distribution 30.08.2012) and also destroys houses of Sorkheh Sangan village and a bridge of Emamzadeh Shafie village in recent flood and we can observe effects of flood erosion. This type of erosion breaks trees beside river and or changes its forms.

\section{Mechanical erosion or erosion resulted from operation of plow and furrow}

This erosion is done due to plow and furrow and returning soil to lower level parts of slope in fact lands that have slope more than $25 \%$ get involved with such erosion and regions of basin in Chalehsara, Seskan, Emamzadeh Shafie and also in region that have sloped farm lands we can observe such erosion.

\section{Slip}

By a glance to geomorphology map of Shanderman basin we observe that at northwest of the region of Aref Jolfa and at northeast of Leilikan village and at the northwest of Sorkhe Sangan village there has been done various slips and covers much area around main river. Slop of these regions wasn't much and has vegetation. Another slip is observed at the south of Sokom village and Virgah by observation of above slips it is seen that mostly have movement less than $10 \mathrm{~m}$ and erosion on slipping mass was average and by comparing severity of erosion in slipping region than surrounding area was more severe. The reason of above slips was high slope, creating communicative roads and geological formations of rain that regarding morphology dominating form of valleys in above area was $U$ form and their drainage system is drainage tree branch and drainage density is average and form of length and width scopes are concave. In this map river and fault cliff are seen. 


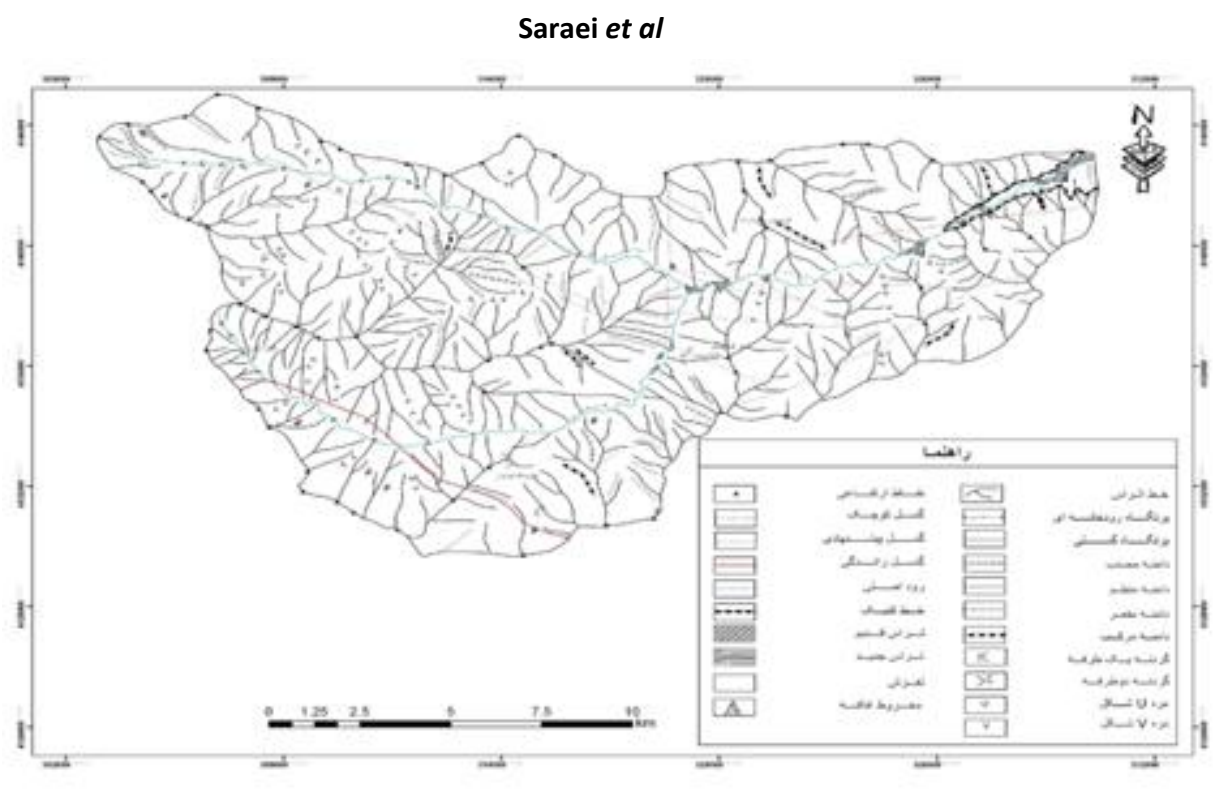

\section{Slide}

In studying area especially in heights that have steep slope and regarding geological formation it was loose beads due to severe rain, glacial, melting ice this phenomenon was active and factors such as constructing new roads activated this phenomenon and flood movements and earthquake specifically in sloping scopes made its danger much more. Regions such as Soposht and lenzeh due to much slope and regions such as Salaro and Sorkheh Sangan due to snow and glacial are affected by this natural events mostly danger of slide happens since 4 a.m to 7 a.m. due to freezing in stones and causes increase of its volume in physical form.

\section{Flood}

Referring to flood statistics in previous years and recent floods and extensive damages remained show that Guilan province is much vulnerable almost all basins of Guilan province are active regarding flooding and only from second half of Aug to Oct in 2008 all rivers of Guilan province have had severe to average flooding activity periodically. One factor that is effective in occurrence of floods of basin is long rains or severe short-time rain and effect of these rains in spring(time of melting snow) can create severe floods of snow melting. Another factor that affects occurrence of flood of basin is resulted from natural phenomenon such as slide of scopes and trees and.. that cause changeor closeness of direction of rivers and in this case exit water from direction and cause flood. Factors affecting flood in Shanderman basin can be divided into main factors (permanent) and strengthening factors (inconsistent). Of course other factors such as physiography, topography, geology andsoonhas significant effect at flooding of basin. By surveying people of the region and field observation the most important events of above basin was flood that in recent years it has become severe regarding change of land use in the basin.

\section{Draught}

Based on statistics of agriculture organization of Masal city the factor of draught has damaged 144.35 hectare of farms of this region and 357 farmers of this city in this region have been damaged that in studying area villages that were in plain section and existed in output of basin were the villages that faced draught. The maximum draught was 878 people in 1995 and then 1999 and 2008 were the years that are the maximum draught. Consideration of wet yearand draught of the basin shows that 7 years of statistical period in Shanderman basin is wet yearand 14 years of statistical period is draught. Also draught and wet yearin above basins have specific order and process. As firstly a continuous draught then a year of continuous wet year and again draught and thereafter a short-time wet year and drought and wet yearand draught.

\section{Considering SPI method in the basin}

Because draught and shortage of rain affects underground waters and soil humidity and flow of rivers standard precipitant ion index(SPI) is used 
to be able to quantify effect of shortage of rain during time range of 3,6,12,24 and ,,, month.

Table 1: SPI classification criteria

\begin{tabular}{|l|l|l|l|l|l|l|l|}
\hline SPI & 2 and more & $\begin{array}{l}1 / 99 \text { to } \\
1 / 5\end{array}$ & $1-1 / 49$ & $\begin{array}{l}0 / 99 \\
\text { to-0/99 }\end{array}$ & $\begin{array}{l}-1 / 49 \text { to } \\
-1\end{array}$ & $\begin{array}{l}1 / 99 \text { to- } \\
-1 / 5\end{array}$ & -2 and less \\
\hline $\begin{array}{l}\text { Weather } \\
\text { condition }\end{array}$ & $\begin{array}{l}\text { Absolutely } \\
\text { humid }\end{array}$ & $\begin{array}{l}\text { Very } \\
\text { humid }\end{array}$ & $\begin{array}{l}\text { Moderate } \\
\text { humid }\end{array}$ & $\begin{array}{l}\text { Near to } \\
\text { normal }\end{array}$ & $\begin{array}{l}\text { Moderate } \\
\text { dry }\end{array}$ & $\begin{array}{l}\text { Very } \\
\text { dry }\end{array}$ & $\begin{array}{l}\text { Absolutely } \\
\text { dry }\end{array}$ \\
\hline
\end{tabular}

As in a statistical period condition of weather is distinguished based on SPI for each year since the time SPI is less than -1 draught starts and up to the time this percipitat is less than -1 shows that draught continues and any time that photo of IPS excess 1 shows start of wet year period. By using SPI precipitate we can search situationof draught of a region over time.

Table 2:SPI classification criteria in Shanderman basin

\begin{tabular}{|l|l|l|l|l|l|l|l|l|l|l|l|l|}
\hline $\begin{array}{l}\text { paramete } \\
\text { rs }\end{array}$ & $\begin{array}{l}\text { Octob } \\
\text { er }\end{array}$ & $\begin{array}{l}\text { Novemb } \\
\text { er }\end{array}$ & $\begin{array}{l}\text { decemb } \\
\text { er }\end{array}$ & $\begin{array}{l}\text { Janua } \\
\text { ry }\end{array}$ & $\begin{array}{l}\text { Februa } \\
\text { ry }\end{array}$ & $\begin{array}{l}\text { Marc } \\
\text { h }\end{array}$ & April & May & June & July & aug & sep \\
\hline rain & $137 / 4$ & $102 / 1$ & $57 / 9$ & $49 / 3$ & $55 / 7$ & $80 / 2$ & $63 / 2$ & $71 / 5$ & $64 / 7$ & $37 / 3$ & $45 / 9$ & $\begin{array}{l}/ 4 \\
117\end{array}$ \\
\hline SPI & $1 / 2$ & 1 & $-0 / 5$ & $-0 / 8$ & $0 / 6$ & $0 / 2$ & $-0 / 3$ & $-0 / 1$ & $-0 / 3$ & $-1 / 2$ & $-0 / 9$ & $1 / 5$ \\
\hline $\begin{array}{l}\text { Weather } \\
\text { conditio } \\
\text { n }\end{array}$ & humid & Normal & Normal & $\begin{array}{l}\text { Norm } \\
\text { al }\end{array}$ & $\begin{array}{l}\text { Norma } \\
1\end{array}$ & $\begin{array}{l}\text { Norm } \\
\text { al }\end{array}$ & $\begin{array}{l}\text { Norm } \\
\text { al }\end{array}$ & $\begin{array}{l}\text { Norm } \\
\text { al }\end{array}$ & $\begin{array}{l}\text { Norm } \\
\text { al }\end{array}$ & $\begin{array}{l}\text { Norm } \\
\text { al }\end{array}$ & $\begin{array}{l}\text { Norm } \\
\text { al }\end{array}$ & $\begin{array}{l}\text { Semi } \\
\text { humi } \\
\text { d }\end{array}$ \\
\hline
\end{tabular}

Regarding above table in SPI method any month in draught basin doesn't exist and 10 month is normal and only September is semi-humid. Whereas every year in the region we have draught.

\section{Conclusion}

Shanderman basin in Masal city is one basin that roots from height of $2800 \mathrm{~m}$ of Saderehsar at the west, Kooh Digah at the northwest and Kooh Dilmeh at the southwest and with various branches after passing a way it passes through different regions like Salaro, lachoor, Bringah, Afjah. Regarding physiography and geometry this river flows at the whole year and this basin is permanent. Density of network of shanderman river was $1.49 \mathrm{~km}$ at $\mathrm{km}^{2}$. Ratio of branch in shanderman basin is 4.24. from shanderman basin was calculated with coefficients such as Horton, Gravilios, inclines, length and ration of stretching and shape of basin is stretching. Average height of basin was $1500 \mathrm{~m}$ and the most surface of basin is located at the height $1700-1800 \mathrm{~m}$. Gross slope of main river of basin was $9 \%$ and time of concentration of basin was calculated through various methods such as Kerpich method, Jiandoti method, Cho method, California 2 method.
Process of average changes of monthly temperature shows that the highest degree of temperature $25.4^{\circ} \mathrm{c}$ was related to Aug and the least temperature with $6.1^{\circ} \mathrm{c}$ is related to Feb. Regardingdays of glacial, in sep, Oct,Nov, Dec, Jan,Feb have glacial days and in March, April,May,June,July ,Aug there hasn't been observed any glacial. Considerations shows that most rains in considering basin occurs in Sep and this month only conforms $27.70 \%$ of annual rains.June,July, Aug, with $4 \%$ of annual rains, are counted the driest month.Regarding monthly rains in Shanderman station the highest rain in oct is $150.2 \mathrm{~mm}$ and the least rain in june is $50.4 \mathrm{~mm}$. In Shanderman station in no month there was less than $50 \mathrm{~mm}$ rain and all months of the year have rain more than $50 \mathrm{~mm}$. Based on existing statistics average days accompanied by cloud in the year are 162.3 days or in other word about 5.5 month that the maximum one was in Feb and the minimum one was in June,July. Fluctuation of flow shows that the highest annul flow with high fluctuation was in year 1993-1994 and the least annual flow was in 1998-1999. Also the highest monthly flow in march with $7.6 \mathrm{M}^{3} /$ second and the least monthly flow is in Aug with $2.6 \mathrm{~m}^{3} / \mathrm{second}$. Regarding 
average flow( $4.6 \mathrm{~m} 3 / \mathrm{second})$ about $70 \%$ of cases of flowof basin is more than average annual flow . Volume of annual dischargeof shandeman basin was estimated 149.8 million $\mathrm{m}^{3} / \mathrm{s}$. The highest degree of volume of flow in March with 20.42 million $\mathrm{m}^{3}$ that devoted $13.63 \%$ of the whole volume of discharge and the least degree of discharge is related to Aug that is distinguished with volume of annual discharge. Height of runoff shows that the highest amount of runoff is related to March that is resulted from degree of rains of spring and melting snow in that month. The least amount of runoff is devoted to Aug. In fact the highest degree of coefficient of runoff is related to March and the least coefficient is related to Sep. The least coefficient of preservation was related to June and the highest coefficient of preservation is in Sep that shows soil at that time was dry regarding weather warmness and saved amount of receiving rain and was changed to runoff. The highest coefficient of flow was related to Aug and the least amount was related to July and Aug that river has the least amount of water flow at that time. Shanderman basin was mountainous topographically and has the highest area of high slope above $20 \%$ although having enriched vegetation it can be effective factor at natural events. Topography of basin denotes that most rural regions were created at the side of river and valleys that regarding mountainous condition of the region and much slope of severity of runoff was more and can be serious danger for rural regions. In studying basin especially in height that slope was steep and regarding geological construction it was loose beads this phenomenon was active due to severe rain, glacial and ice melting and factors such as constructing new roads activated this phenomenon and flood flows and earthquake increased its dangers at high slope regions such as Soposht and lenzeh due to much slope and regions such as Masir Salaro and Sorkheh sangan due to snow melting and glacial are affected by these natural events Mostly danger of slide was created at $4 \mathrm{a} . \mathrm{m}$ to $7 \mathrm{a} . \mathrm{m}$ due to freezing of stones and causes expansion of its volume in physical mode. Consideration of SPI method there isn't any month of draught in this basin and 10 month are normal and a month is humid and only sep is semi-humid. Whereas every year in this region we have draught. Regarding consideration of natural dangers in basin there are various dangers that can be related to topographical conditions, geology, vegetation, slope, climate and .. in basin. Totally the most dangers in the basin was flood and after that erosion and erosion beside river comparing to other forms has severe erosion that in recent years by change of land use at basin surface and destruction of vegetatin these dangers have strengthens. Therefore factor of erosion and flood is counted as the most important danger of shanderman basin.

\section{Resources}

Abedi, G. 1999. Considering natural events and its role at constant development by emphasizing Iran, Sepehr, technical journal of geography organization of country, seventh period, No 28 , winter.

Afshari, A. 2004. Engineering hydrology, center of university press, second edition.

Agriculture ministry, 1993. Applied map and coverage of lands of scale 1:100000 of Anzali sheet.

Alijani, B., Kaviani, M. 1992. Principles of weather and meterology, publication of samt in Tehran.

Alijani, B., Kaviani, M. 2000. Iran weather, samt publication in Iran.

Alizadeh E. 2005. Weather and climatology, publication of Ferdosi University in mashhad, second edition.

Alizadeh, A. 2007. Applied hydrology principles, $22^{\text {nd }}$ edition, astan e ghods e Razavi.

Alizadeh, H. 2004. The greatest flood in hydrology (case study of Gorganrood Talesh basin, research plan of Islamic Azad university of Rasht.

Army geography organization, 2005. Topographical map of scale 1:50000, Masal and Taharom

Behbahani, S. M. 2002. Hydrology of superficial waters, publication of Tehran University.

Consulting engineers of Pendam, 1993. Studies of identifying head branches of a number of rivers in Guiln province, soil report. 


\section{Studying and identifying natural dangers}

Farajzadeh, M. 2004. Draught from concept to procedure, publication of geography press, first edition.

Geology organization of country, 2003. geology map of Anzali sheet, 1:100000.

Geology organization of Guilan province, 2009. climate data of studying region.

Jafarpour, E. 1999. Climatology, publication of payam e Noor University.

Kate S. 2003. Translation of Moghimi and Goodarzinezhad, Shapour, Environmental dangers, samt press.

Khaledi, Sh. 2001. Natural events, publication of shahid Beheshti university.

Mahdavi, M. 1999. General hydrology, cultural and publication institution of ayeh.
Ministry of agriculture, 1991. Map of capability and talent of lands of Guilan province, institution of water and soil.

Movahed Danesh, A. 1994. Hydrology of surface waters of Iran, Tehran, samt, first edition.

Ramezani, B. 2003. Considering and identification of factors of flood in Aug in 1999 at masouleh in Guilan, events No 101.

Ramezani, B., Abdollahi, A. 2003. Considering rainrunoff of basin of masouleh city in Gilan, Sepehr journal, No 41 .

Refahi, H. 1999. Water erosion and controlling it, publication of Tehran University.

Regional water organization in Guilan province, 2011. Geology data and hydrometery of studying stations.

Rezaei Hajidehi, P. 2009. Convergent analysis of flood in Masouleh basin, researches of natural geography, No 68. 